To the Editors:

\title{
Dengue fever and ionized calcium levels: significance of detecting hypocalcaemia to predict severity of dengue
}

\author{
N J Dahanayaka ${ }^{1}$, S B Agampodi ${ }^{2}$, U P Kodithuwakku Arachchi ${ }^{3}$, S P Vithange ${ }^{1}$, R Rajapakse ${ }^{1}$, \\ K Ranathunga $^{1}$, S Siribaddana ${ }^{1}$ \\ Ceylon Medical Journal 2017; 62: 67-69 \\ DOI: http://doi.org/10.4038/cmj.v62i1.8438
}

Low total serum calcium is unknown to occur in more than $80 \%$ of patients with dengue fever (DF) [1]. Unlike serum total calcium, serum ionized calcium (SIC) is not affected by other factors. A recent study revealed that SIC levels were significantly lower and hypocalcaemia was more prevalent in patients with dengue haemorrhagic fever (DHF) than in patients with DF [2].

Most of the complications in DHF are due to plasma leakage leading to third space fluid accumulation (TSFA) in pleural and peritoneal cavities. Ultrasound Scan provides a quick assessment of TSFA. In previous studies TSFA was not objectively measured and ionized calcium levels were not serially done during hospital stay [1, 2].

We carried out a cross sectional study at University Medical Unit (UMU), Teaching Hospital Anuradhapura (THA) from January to May 2014 to assess the distribution of SIC during DF and to assess the association between hypocalcaemia with TSFA and other organ involvement. Consecutive probable DF patients who were admitted to UMU, THA were recruited to the study after obtaining informed written consent. Ethical approval was obtained from Ethics Review Committee, Faculty of Medicine and Allied Sciences, Rajarata University of Sri Lanka.

Case confirmation was done using dengue NS1 antigen test [Standard Diagnostics BIOLINE, Kyonggi, Korea (immunochromatographic method)] or dengue IgM antibodies [Standard Diagnostics BIOLINE, Kyonggi, Korea (immunochromatographic method)]. A SIC level of $<1.1 \mathrm{mmol} / \mathrm{l}$ was defined as hypocalcaemia.

Blood samples were obtained on admission and every morning till the patient recovered. All investigations were done in a single laboratory. Ion electrode selective method was used to determine SIC levels. All patients underwent ultrasound scans on admission and daily in the morning. It was carried out by two MBBS qualified medical officers. The consultant radiologist at THA interpreted the saved scan images.

Of the 36 probable cases of dengue recruited for this study, 31 (86.1\%) were confirmed by detecting NS1 antigen ( $\mathrm{n}=07)$, dengue antibodies (IgM) $(\mathrm{n}=05)$ or both $(n=19)$. Majority of confirmed cases $(n=26)$ were males and mean age was $32.6 \pm 11.2$ years. Among confirmed cases, SIC levels from fever day 3 to 10 were available (Table 1). These values ranged from 0.79 to $1.34 \mathrm{mmol} / \mathrm{l}$. Seventeen (54.8\%) of the confirmed cases either had hypocalcaemia on admission $(n=13)$ or developed it during hospital stay $(n=4)$. Most of them were first detected as having hypocalcaemia $(\mathrm{n}=10)$ on day 6 and 7 of fever. None of the patients with hypocalcaemia had clinical features suggestive of hypocalcaemia or received calcium supplementation. In all serum calcium levels became normal within a day or two.

Five patients developed TSFA. Three of them had TSFA and hypocalcaemia on admission (Table 2). Two more patients developed TSFA after admission and they too developed hypocalcaemia before or at the time of first detection of TSFA. None of the patients with normocalcaemia developed TSFA. Positive and negative predictive values of hypocalcaemia predicting TSFA was $29 \%$ and $100 \%$ respectively with a positive likelihood ratio of 2.17 (95\% CI 1.84-2.551). Mean SIC (lowest) among patients with TSFA was 0.97 (SD 0.1) $\mathrm{mmol} / \mathrm{l}$ compared to 1.12 (SD 0.14) $\mathrm{mmol} / \mathrm{l}$ among those without TSFA $(p=0.035)$.

Patients with hypocalcaemia had significantly lower platelet count and serum albumin levels (Table 3). All five patients with platelet count $<20000 \times 109 / \mathrm{L}$ had

Departments of ${ }^{1}$ Medicine and ${ }^{2}$ Community Medicine, Faculty of Medicine and Allied Sciences, Rajarata University of Sri Lanka and ${ }^{3}$ Teaching Hospital Anuradhapura Sri Lanka.

Correspondence: NJD, e-mail: : <niroshanajd@yahoo.com>. Received 5 September 2016 and revised version accepted 14 December 2016. 2016.

This is an open-access article distributed under the terms of the Creative Commons Attribution License, which permits unrestricted use, distribution, and reproduction in any medium, provided the original author and source are credited. 
hypocalcaemia. However, there was no significant difference in lowest mean white cell count and highest mean AST/ALT levels (Table 3). None of the patients developed features suggestive of myocarditis or encephalitis.

These findings raise several unanswered questions on the role of calcium in dengue. In in-vitro studies, presence of calcium ion is obligatory for cytotoxic activity of the dengue virus and the cell death is associated with increased intracellular calcium ion concentration [3]. Therefore, one can postulate that hypocalcaemia due in DF could be due to influx of calcium and calcium replacement could enhance the dengue virus activity by increasing intracellular calcium ion concentration. This can be supported by in vitro studies showing calcium channel blockers inhibiting the activity of the influx of calcium ion to macrophages and $\mathrm{T}$ cells reducing the disease activity of dengue [4]. However, there is only very limited evidence on calcium supplementation in dengue fever [5].

\section{Table 1. Detection and recovery of hypocalcaemia in confirmed cases of dengue patients according to day of fever}

\begin{tabular}{|c|c|c|c|c|c|}
\hline $\begin{array}{l}\text { Duration of } \\
\text { fever } \\
\text { (days) }\end{array}$ & $\begin{array}{l}\text { Number of patients } \\
\text { whose calcium } \\
\text { values are available }\end{array}$ & $\begin{array}{l}\text { Number of } \\
\text { patients with } \\
\text { hypocalcaemia }\end{array}$ & $\begin{array}{l}\text { Number of patients } \\
\text { first detected with } \\
\text { hypocalcaemia }\end{array}$ & $\begin{array}{l}\text { Number of patients } \\
\text { whose calcium level } \\
\text { normalized from } \\
\text { low levels }\end{array}$ & $\begin{array}{c}\text { Serum ionized } \\
\text { calcium }(\mathrm{mmol} / \mathrm{L}) \\
\text { Mean }(\mathrm{SD})\end{array}$ \\
\hline 3 & 2 & 1 & 1 & 0 & $1.10 \quad(0.01)$ \\
\hline 4 & 7 & 3 & 3 & 1 & $1.15(0.11)$ \\
\hline 5 & 14 & 4 & 1 & 0 & $1.15(0.11)$ \\
\hline 6 & 20 & 7 & 5 & 2 & $1.14 \quad(0.12)$ \\
\hline 7 & 24 & 9 & 5 & 3 & $1.16 \quad(0.12)$ \\
\hline 8 & 20 & 3 & 1 & 7 & $1.21 \quad(0.10)$ \\
\hline 9 & 6 & 2 & 1 & 2 & $1.16(0.21)$ \\
\hline 10 & 2 & 0 & 0 & 2 & $1.25(0.06)$ \\
\hline
\end{tabular}

Table 2. Serum ionized calcium ( $\mathrm{mmol} / \mathrm{l})$ levels among five confirmed cases of dengue fever with third spaced fluid accumulation

\begin{tabular}{|c|c|c|c|c|c|c|c|}
\hline \multicolumn{8}{|c|}{ Serum ionized calcium (mmol/l) } \\
\hline Patient ID & Day 3 & Day 4 & Day 5 & Day 6 & Day 7 & Day 8 & Day 9 \\
\hline 1 & 1.10 & 1.25 & 1.23 & $1.30 *$ & $1.20 * *$ & & \\
\hline 2 & & & & & $1.06 *$ & $1.30 * *$ & 1.36 \\
\hline 3 & & & 1.19 & $0.98 *$ & $1.08 * *$ & 1.20 & \\
\hline 4 & & $1.09 *$ & 0.90 & $1.23 * *$ & 1.28 & 1.20 & \\
\hline 5 & & $0.99 *$ & 1.02 & $1.11 * *$ & 0.85 & 1.15 & \\
\hline
\end{tabular}

*indicates the date of first detection of fluid leak $\quad * *$ indicates the day of maximum fluid leak low serum calcium levels are in bold

Table 3. TSFA, platelet count, white cell count and albumin level according to serum ionized calcium level

\begin{tabular}{lccc}
\hline \multicolumn{2}{c}{ Hypocalcaemia } \\
& Yes $(17)$ & No $(14)$ & P value \\
\hline Lowest mean platelet count $(109 / \mathrm{L})$ & $40,529( \pm 25809)$ & $61,357( \pm 30457)$ & $0.048^{*}$ \\
Platelet count $<20000 \times 109 / \mathrm{L}$ & $5(29.4 \%)$ & 0 & $0.027^{*}$ \\
Lowest mean WCC $\left(\times 10^{9} / \mathrm{L}\right)$ & $3.35( \pm 1.79)$ & $3.2( \pm 1.74)$ & 0.856 \\
Lowest mean albumin level $(\mathrm{g} / \mathrm{L})$ & $32.7( \pm 0.34)$ & $36.9( \pm 0.31)$ & $0.001^{*}$ \\
Highest mean AST $(\mathrm{IU} / \mathrm{L})$ & $309.6( \pm 306.6)$ & $238.5( \pm 141.9)$ & 0.431 \\
Highest mean ALT $(\mathrm{IU} / \mathrm{L})$ & $189( \pm 184.9)$ & $183( \pm 118)$ & 0.916 \\
Albumin level $<35 \mathrm{~g} / \mathrm{L}$ & $10(58.8 \%)$ & $3(21.4 \%)$ & $0.036^{*}$ \\
\hline
\end{tabular}

\footnotetext{
*significant at $\mathrm{p}<.05$
}

WCC white cell count, AST aspartate amino transferase, ALT alanine amino transferase 
We recommend carrying out prospective studies to examine use of serum calcium level as predictor of TSFA and carrying out randomised controlled studies on oral and intravenous calcium replacement for dengue fever patients to assess its role in prevention of complications and clinical recovery.

\section{Funding}

This study was partly supported by the Rajarata University of Sri Lanka. [Grant number RJT/RP \& HDC/ 2013/Med.\&Alli.Sci./R/08]

\section{Acknowledgements}

We would like to thank Mediquipment Limited Sri Lanka for providing an ultra sound scan machine to carry out this study and Durdans Laboratory, Anuradhapura for carrying out all the investigations.

\section{Conflicts of interest}

There are no conflicts of interest.

\section{References}

1. Bunnag, T, Kalayanarooj S. Dengue shock syndrome at the emergency room of Queen Sirikit National Institute of Child Health, Bangkok, Thailand. J Med Assoc Thai 2011; 94 Suppl 3: S57-63.

2. Constantine GR, Rajapakse S, Ranasinghe P, Parththipan B, Wijewickrama A, Jayawardena P. Hypocalcemia is associated with disease severity in patients with dengue. $J$ Infect Dev Ctries 2014; 8: 1205-9.

3. Khanna M, Chaturvedi UC, Dhawan R, Tekwani BL, Pandey VC. Presence of $\mathrm{Ca} 2+$ is obligatory for the cytotoxic activity of dengue virus-induced cytotoxic factor. Immunology 1991; 72: 73-8.

4. Dhawan R, Chaturvedi UC, Khanna M, Mathur A, Tekwani BL, Pandey VC, Rai R N. Obligatory role of $\mathrm{Ca} 2+$ in the cytotoxic activity of dengue virus-induced cytotoxin. Int $J$ Exp Pathol 1991; 72: 31-9.

5. Cabrera-Cortina JI, Sánchez-Valdéz E, Cedas-DeLezama D, Ramírez-González MD. Oral calcium administration attenuates thrombocytopenia in patients with dengue fever. Report of a pilot study. Proc West Pharmacol Soc 2008; 51: 38-41. 